\title{
Effect of Ambient Temperature on Performance of Grid-Connected Inverter Installed in Thailand
}

\author{
Kamonpan Chumpolrat, Vichit Sangsuwan, Nuttakarn Udomdachanut, \\ Songkiate Kittisontirak, Sasiwimon Songtrai, Perawut Chinnavornrungsee, \\ Amornrat Limmanee, Jaran Sritharathikhun, and Kobsak Sriprapha
}

National Electronics and Computer Technology Center, 112 Thailand Science Park, Phahonyotin Road, Klong 1, Klong Luang, Pathumthani 12120, Thailand

Correspondence should be addressed to Kamonpan Chumpolrat; kamonpan.chumpolrat@nectec.or.th

Received 28 October 2013; Revised 7 January 2014; Accepted 4 February 2014; Published 6 March 2014

Academic Editor: Adel M. Sharaf

Copyright (C) 2014 Kamonpan Chumpolrat et al. This is an open access article distributed under the Creative Commons Attribution License, which permits unrestricted use, distribution, and reproduction in any medium, provided the original work is properly cited.

\begin{abstract}
The effects of temperature on performance of a grid-connected inverter, and also on a photovoltaic (PV) system installed in Thailand have been investigated. It was found that the maximum efficiency of the inverter showed $2.5 \%$ drop when ambient temperature was above $37^{\circ} \mathrm{C}$. The inverter performed efficiently in November and December, the months of high irradiance, and monthly average ambient temperature of lower than $35^{\circ} \mathrm{C}$, allowing relatively high system performance ratio in this period. Our results show that high temperature provides negative impacts not only on the PV modules, but also on the performance of the inverter. Thus, the effect of temperature on the inverter efficiency should be taken into account when predicting energy yield or analyzing losses of the PV systems-especially in high temperature regions.
\end{abstract}

\section{Introduction}

Thailand receives an annual average solar irradiation of $18.2 \mathrm{MJ} / \mathrm{m}^{2}$ - day, which is relatively high compared to other tropical and mid-latitude counties [1]. Owing to abundant solar energy and government support scheme for megawatts solar farms, Thailand is expected to be an emerging photovoltaic (PV) market of Southeast Asia. Nonetheless, severe climatic conditions of tropical countries-high temperature and high humidity-have negative impacts on performance and reliability of PV systems. Since high temperature causes a reduction in output power of PV modules, the temperature effects are one of main concerns when forecasting energy production or analyzing losses of the PV systems. There are, thus, many reports regarding the effects of temperature on the performance of various types of PV modules operating in tropical countries including Thailand [2-5]. Besides the performance of the PV modules, inverter efficiency is also a critical factor which greatly influences the system performance; therefore, its actual behavior needs to be evaluated. Furthermore, temperature-dependent performance of inverter is also worth investigating because the efficiency of electronic devices including inverter also depends on the operating temperature [6-9]. Since the temperaturedependent behavior of the inverter for PV systems has not yet been reported, in this study we have investigated performance of a high-efficient grid-connected inverter installed in Thailand, in particular with respect to the temperature effect. The findings of our work are expected to be useful information for energy yield prediction and loss analysis of the PV systems, especially in high temperature regions.

\section{System Installation and Monitoring}

The $2.24 \mathrm{kWp}$ grid-connected PV system has been installed at National Science and Technology Development Agency (NSTDA), Pathumthani province, Thailand-latitude $14^{\circ} 4^{\prime} 46^{\prime \prime} \mathrm{N}$, longitude $100^{\circ} 36^{\prime} 4^{\prime \prime} \mathrm{E}$-in March 2010, supplying electricity for load of the office building. This PV system consists of tandem amorphous silicon (a-Si:H/a$\mathrm{Si}: \mathrm{H})$ prototype modules manufactured by NSTDA. The characteristics of the PV modules, inverter, and the PV system in this study are described in Table 1 . The PV modules have been installed in an open rack at a tilt of $14^{\circ}$ facing 
TABLE 1: PV module and system characteristics.

\begin{tabular}{lcc}
\hline Item & & Details \\
\hline & Type & Thin film a-Si \\
Module & Peak power output & $40 \mathrm{~W}$ \\
& Peak power voltage & $47.5 \mathrm{~V}$ \\
& Peak power current & $0.84 \mathrm{~A}$ \\
& Temperature coefficient for power & $-0.20 \% /{ }^{\circ} \mathrm{C}$ \\
& Area & $1.2 \mathrm{~m} \times 0.65 \mathrm{~m}\left(0.78 \mathrm{~m}^{2}\right)$ \\
Inverter & Type & Single-phase string, transformer based, grid-connected \\
& Nominal output power & $5 \mathrm{~kW}$ \\
& Maximum efficiency & $96 \%$ \\
System & Number of modules & $56(8 \mathrm{modules} / \mathrm{string}, 7 \mathrm{strings})$ \\
& Nominal power output & $2.24 \mathrm{~kW}$ \\
& Peak power voltage & $380 \mathrm{~V}$ \\
\end{tabular}

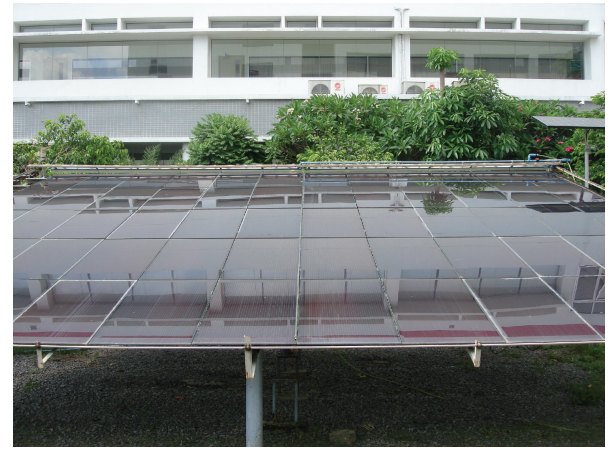

Figure 1: PV test site at NSTDA, Thailand.

South, as shown in Figure 1. An automated measuring system was constructed to collect data of the system, that is, system output, module temperature $\left(T_{m}\right)$, ambient temperature $\left(T_{a}\right)$, and in-plane solar irradiance, at $1 \mathrm{~min}$ interval. The collected data from $5 \mathrm{AM}$ to $7 \mathrm{PM}$ during the period of 7 months (from October 2010 to April 2011) was used for the system performance analysis in this study.

\section{Results and Discussion}

The DC output power as a function of the solar intensity and a variation of the module temperature are shown in Figure 2. It can be seen that the module temperature was about $30^{\circ} \mathrm{C}$ under the irradiance of lower than $250 \mathrm{~W} / \mathrm{m}^{2}$ and then gradually increased with increasing irradiance, rising to $60^{\circ} \mathrm{C}$ at the irradiance of $800-1000 \mathrm{~W} / \mathrm{m}^{2}$. It should be noted that in this test site the average module temperature ranged from $42^{\circ} \mathrm{C}$ to $47^{\circ} \mathrm{C}$, rarely being $25^{\circ} \mathrm{C}$ or lower during the operating hours. Figure 3 indicates a linear relationship between the DC output from the PV modules (inverter input power) and the AC output from the inverter. The inverter started to produce the AC output at the DC output power of about $58 \mathrm{~W}$, suggesting energy consumption of $58 \mathrm{~W}$ at its operating mode.

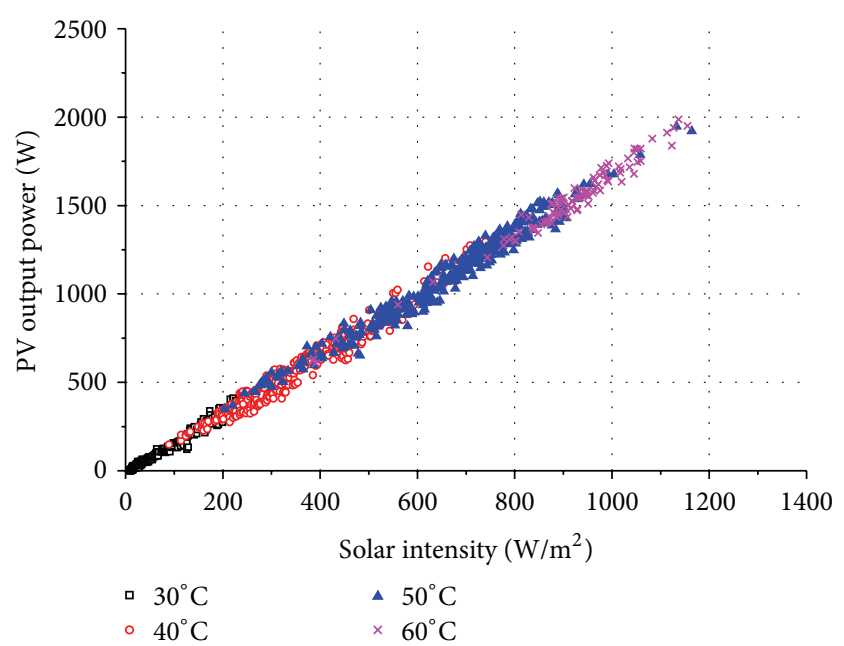

FIGURE 2: Relation of solar irradiance to PV output power and variation in module temperature.

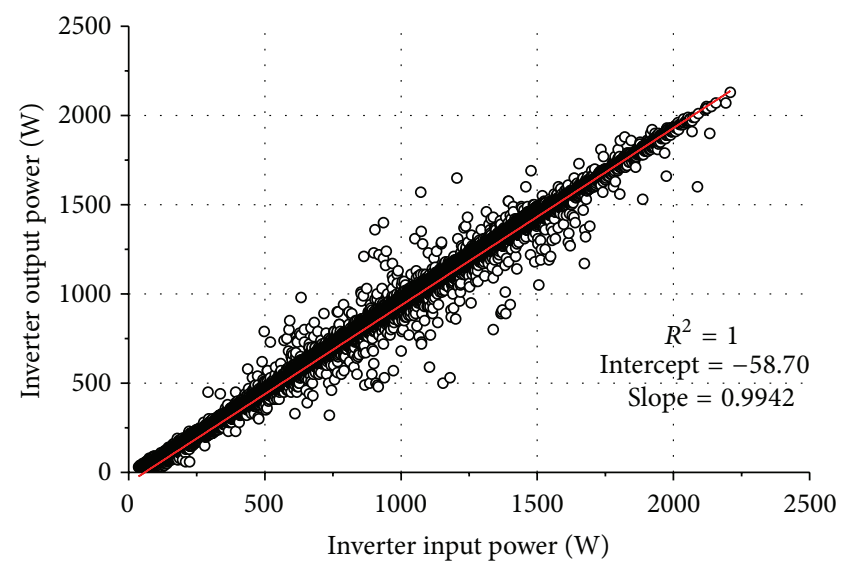

FIgURE 3: Relation between input and output power of inverter.

Interestingly, it was found that the actual maximum efficiency of the inverter strongly depended on the ambient temperature. As shown in Figure 4, the inverter efficiency 


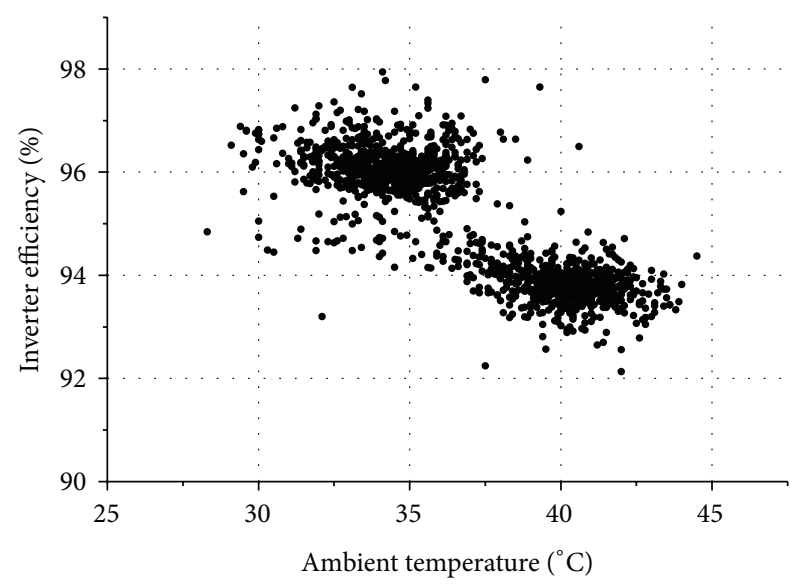

FIGURE 4: Relation between inverter efficiency and ambient temperature.

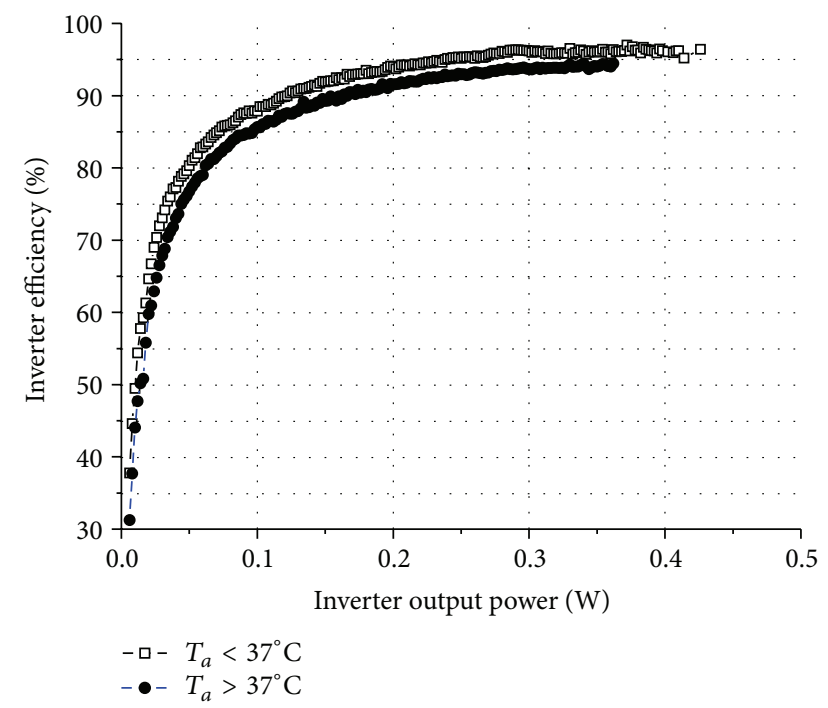

FIGURE 5: Average inverter efficiency of two different operating conditions: $T_{a}<37^{\circ} \mathrm{C}$ and $T_{a}>37^{\circ} \mathrm{C}$.

$\left(\eta_{\text {ivt }}\right)$ reaches its maximum value of $96-96.5 \%$ when the ambient temperature is below $37^{\circ} \mathrm{C}$ and shows $2.5 \%$ drop when the temperature increases above $37^{\circ} \mathrm{C}$ - under the same solar irradiance of $1000-1100 \mathrm{~W} / \mathrm{m}^{2}$. An obvious difference in the inverter efficiency of two different operating conditions, of which $37^{\circ} \mathrm{C}$ is set as a borderline, is displayed in Figure 5. In both cases the inverter efficiency similarly tended to remain constant when the AC output power exceeded $1500 \mathrm{~W}$ or $27 \%$ of the inverter's rated capacity; however, the difference in the inverter efficiency of these two different temperatures was obvious.

It is well known that the characteristics of the inverter are dependent on the temperature of the electronic circuittemperature inside the inverter case. Although we did not collect continuous data of the temperature inside the inverter, we occasionally checked it and found its relation to the ambient temperature. The inverter temperature is always higher than the ambient temperature. During the day time, a temperature difference of about $10-14^{\circ} \mathrm{C}$ is found when the ambient temperature rises higher than $32^{\circ} \mathrm{C}$. This implies that the ambient temperature of $37^{\circ} \mathrm{C}$ corresponds to the inverter temperature of about $47-51^{\circ} \mathrm{C}$. The grid-connected inverter in this study is a single-phase string inverter with transformer. It contains 3 major parts; Maximum Power Point (MPP) tracking, bridge, and transformer. Among these three parts, bridge is the part that is the most sensitive to the operating temperature because it contains switching devices. The temperature effects possibly can be mitigated by optimizing inverter topology and its internal design. A separation of different types of components into different temperature zones within the inverter's overall enclosure is concerned to be an effective way. This approach is generally utilized in low frequency transformer-based inverter design [10]. Since transformer causes heating and also induces power loss, development of a transformerless inverter is likely to be preferable in respect to the temperature effect. Additionally, an efficient cooling system is essential to maintain performance and extend lifetime of the inverter.

The experimental results have revealed the temperaturedependent behavior of the inverter and moreover clearly pointed out negative impact of high temperature on the inverter performance [7]. In high temperature regions, the operating temperature of the inverter, thus, is a critical factor, which should be concerned when analyzing the losses in the PV systems.

Normalized frequency distributions of four different inverter operating conditions are shown in Table 2. Here, the input power of $27 \%$ of the inverter's rated capacity and the ambient temperature of $37^{\circ} \mathrm{C}$ are used as borderline conditions. It can be seen that the conditions whose $T_{a}>37^{\circ} \mathrm{C}$ (numbers 2 and 4 ) occupied 33\% of the total frequency distribution, indicating relatively high possibility of undesirable operating conditions for the inverter. Furthermore, the ideal condition, normalized input power $>27 \%$ and $T_{a}<37^{\circ} \mathrm{C}$, occupied only $11 \%$. In this test site the normalized frequency distribution of the low input conditions (numbers 3 and 4) was found to be as high as $80 \%$. This was because the installed PV module capacity was $2.24 \mathrm{kWp}$, only $45 \%$ of the inverter's rated capacity.

The monthly cumulative solar irradiance-which is here denoted by solar energy received $\left(E_{r}\right)$ - and the monthly average ambient temperature are shown in Figure 6. The average ambient temperature from October 2010 to December 2010 was found to be lower than $35^{\circ} \mathrm{C}$, while from January 2011 to April 2011 the temperature increased above $35^{\circ} \mathrm{C}$. In this test site the $E_{r}$ ranged from 5 to $6.5 \mathrm{MWh}$, especially being high in January. The monthly average inverter efficiency, performance ratio (PR) of the PV modules, and PR of the PV system are indicated in Figure 7. It is obvious that the inverter efficiency was strongly affected by the ambient temperature, that is, high efficiency during lowtemperature period and less efficient performance during high-temperature months. The high average inverter efficiency was observed in November and December, when the average ambient temperature was lower than $35^{\circ} \mathrm{C}$ and their monthly cumulative irradiance was relatively high. Since the inverter efficiency is directly proportional to the 
TABLE 2: Normalized frequency distributions of four different inverter's operating conditions.

\begin{tabular}{lccc}
\hline Number & Inverter's operating conditions & Normalized frequency (\%) \\
\hline 1 & $>27$ & $T_{a}\left({ }^{\circ} \mathrm{C}\right)$ & 11 \\
2 & $>27$ & $<37$ & 9 \\
3 & $<27$ & $>37$ & 56 \\
4 & $<27$ & $<37$ & 24 \\
\hline
\end{tabular}

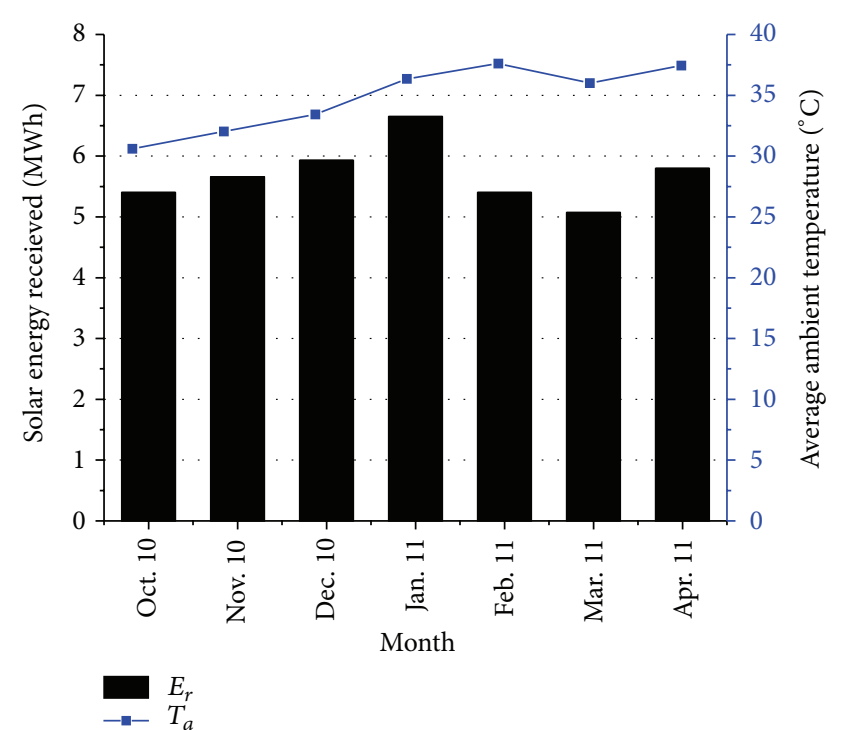

FIGURE 6: Trends of monthly solar energy received $\left(E_{r}\right)$ and average ambient temperature $\left(T_{a}\right)$.

solar intensity, higher efficiency should be observed in the month of higher irradiance; however, in January, the month of the highest monthly cumulative irradiance, the inverter efficiency was found to be relatively low. This was perhaps due to high temperature in January, demonstrating the temperature effects on the inverter performance. Although the highest inverter efficiency was obtained in December, the PR of the thin film a-Si:H modules significantly dropped, which was likely to be caused by the red-shift spectrum distribution during this period [11-14]. The PR of the PV modules tended to recover in January; however, it was still low due to high temperature during January 2011-April 2011, which eventually resulted in the low system PR. According to the results, the PR of the PV system depended on both PV module and inverter performance, both of which were strongly influenced by the operating temperature.

The output energy of the PV system can be expressed by the following equation, which is the modified equation of a method previously used for field-test analysis of PV system output [15]:

$$
P_{\text {out }}=K_{T} \cdot K_{\mathrm{ivt}} \cdot K_{e} \cdot P_{\mathrm{in}} \cdot \eta_{s},
$$

where $P_{\text {out }}$ is AC output energy, $P_{\text {in }}$ is in-plane irradiance, and $\eta_{s}$ is conversion efficiency of the PV modules under the standard testing conditions (STC)-irradiance of

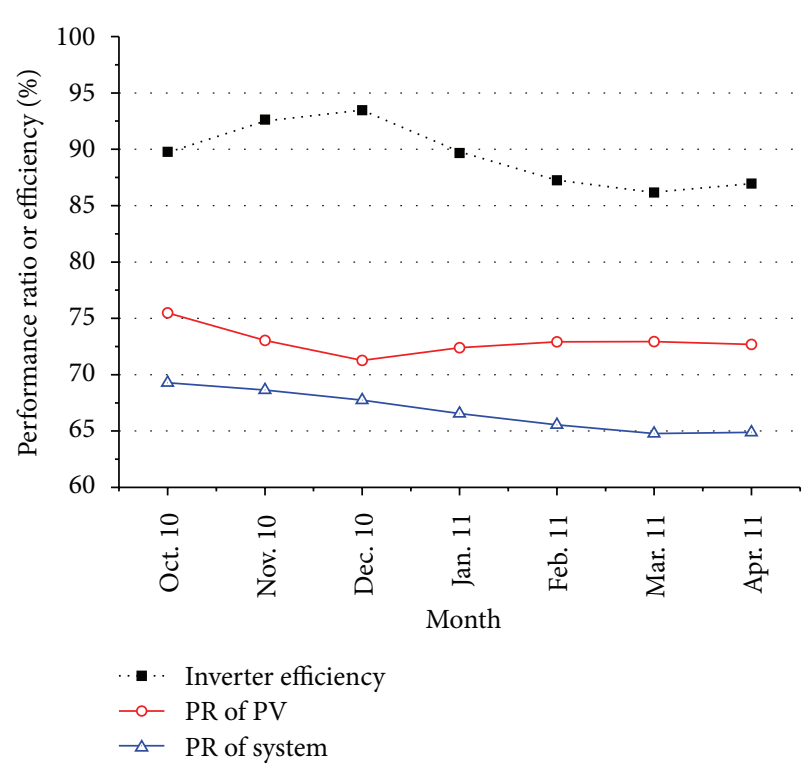

FIGURE 7: Trends of monthly inverter efficiency, PR of PV modules, and PR of PV system.

$1000 \mathrm{~W} / \mathrm{m}^{2}$, module temperature of $25^{\circ} \mathrm{C}$, and air mass 1.5 global spectrum. $K_{T}$ denotes a correction coefficient for module temperature, which can be given by

$$
K_{T}=1+\alpha \cdot\left(T_{m}-25\right),
$$

where $\alpha$ is a temperature coefficient for power of the PV module, which is $-0.20 \% /{ }^{\circ} \mathrm{C}$ in this case. $K_{\text {ivt }}$ is a correction coefficient for inverter performance. Here, the $K_{\text {ivt }}$ is expressed by the following equation:

$$
K_{\mathrm{ivt}}=\eta_{\mathrm{ivt}}^{\circ} \cdot \alpha_{\mathrm{ivt}}=\eta_{\mathrm{ivt}}^{*}
$$

where $\eta_{\mathrm{ivt}}^{\circ}$ is the nominal maximum efficiency of the inverter, $\alpha_{\mathrm{ivt}}$ is a correction factor for inverter efficiency, and $\eta_{\mathrm{ivt}}^{*}$ is the actual efficiency of the inverter. It is well known that the inverter efficiency depends mainly on the input DC power, which corresponds directly to the solar irradiance, thus the variation of the inverter efficiency can be presented in terms of the solar irradiance. However, the inverter efficiency under high-irradiance condition-irradiance $>500 \mathrm{~W} / \mathrm{m}^{2}$-tended to be saturated and remained constant; the correction factor for the inverter performance is, therefore, presented as the approximate equation (3). A correction coefficient for factors except module temperature and inverter performance, which includes effects of shading, reflection, soiling, and 
TABLE 3: The monthly basis of irradiance, average ambient temperature, average module temperature, and correction coefficients.

\begin{tabular}{lcccrrr}
\hline Month & Irradiance $(\mathrm{MWh})$ & Ambient temp. $\left({ }^{\circ} \mathrm{C}\right)$ & $\begin{array}{c}\text { Irradiance weighted } \\
\text { module temp. }\left({ }^{\circ} \mathrm{C}\right)\end{array}$ & $K_{T}$ & $K_{\mathrm{ivt}}$ \\
\hline Oct. 10 & 5.398 & 30.6 & 47.5 & 0.955 & 0.898 \\
Nov. 10 & 5.654 & 32.0 & 49.8 & 0.950 & 0.926 \\
Dec. 10 & 5.926 & 33.4 & 49.7 & 0.951 & 0.935 \\
Jan. 11 & 6.648 & 36.3 & 49.6 & 0.951 & 0.897 \\
Feb. 11 & 5.398 & 37.6 & 49.2 & 0.761 \\
Mar. 11 & 5.071 & 36.0 & 46.5 & 0.952 & 0.873 \\
Apr. 11 & 5.795 & 37.4 & 49.2 & 0.957 & 0.862 & 0.787 \\
\hline
\end{tabular}

degradation, is denoted by $K_{e}$. The $P_{\text {in }}, P_{\text {out }}, T_{m}$, and $\eta_{\text {ivt }}^{*}$ were obtained from the field-test data, while the $\eta_{s}$ and $\eta_{\text {ivt }}^{\circ}$ were known values; therefore, the $K_{T}, K_{\text {ivt }}$, and $K_{e}$ can be derived to evaluate the effects of module temperature, inverter efficiency, and other factors on the PV system performance.

We have derived the correction coefficients, $K_{T}, K_{\text {ivt }}$, and $K_{e}$ and summarized in Table 3 . These correction coefficients, whose value must be $>0$ and $<1$ can be used as primary indicators of energy loss; thus, we can simply compare the losses due to module temperature, inverter, and other factors. It can be seen that the $K_{T}$ did not show obvious variation, while the $K_{\text {ivt }}$ tended to depend on the monthly average ambient temperature. During high-temperature period, the $K_{\text {ivt }}$ was found to be small, suggesting a large amount of energy loss of the inverter. Interestingly, the $K_{e}$ in December was obviously smaller than that of the other months. This was perhaps due to increased spectrum mismatch loss during that period which resulted in the PR drop of the thin film a-Si:H modules.

The efficiency of the inverter, needless to say, certainly influences the total performance of the PV systems. The temperature effects on the inverter is thus a meaningful finding, and the quantitative analysis of this kind of loss is useful for forecasting energy yield of the PV systemsespecially in high temperature regions. Although, at present we have evaluated and analyzed the results of only one highefficient inverter, it is certain that high operating temperature has negative effects on all inverters. However, the amount of loss perhaps depends on inverter's type and manufacture, which is worth investigating further.

\section{Conclusion}

High temperature has negative impacts also on the performance of the inverter, not only on the PV modules. According to our experimental results, the ambient temperature of higher than $37^{\circ} \mathrm{C}$ caused $2.5 \%$ drop in the inverter's maximum efficiency. During high-temperature period, when the monthly average ambient temperature was $>35^{\circ} \mathrm{C}$, the $\mathrm{PR}$ of the PV system was found to be low, which was likely to be due to a large amount of loss arising from high operating temperature. Consequently, in high temperature regions like Thailand the effect of temperature on the inverter performance cannot be neglected, and it must be taken into account in the energy yield prediction or the loss analysis of the PV systems.

\section{Conflict of Interests}

The authors declare that there is no conflict of interests regarding the publication of this paper.

\section{References}

[1] S. Janjai, Solar Radiation Maps from Satellite Data for Thailand, Department of Alternative Energy Development and Efficiency, Ministry of Energy, Bangkok, Thailand, 2010.

[2] W. Suponthana, N. Ketjoya, W. Rakwichian, and P. Inthanon, "Performance evaluation AC solar home systems in Thailand: system using multi crystalline silicon PV module versus system using thin film amorphous silicon PV module," International Journal of Renewable Energy, vol. 2, no. 2, pp. 35-52, 2007.

[3] K. Phaobkaew, N. Ketjoy, W. Rakwichian, and S. Yammen, "Performance of a-Si, p-Si, and HIT PV technological comparison under tropical wet climate condition," International Journal of Renewable Energy, vol. 2, no. 2, pp. 23-34, 2007.

[4] A. Sasitharanuwat, W. Rakwichian, N. Ketjoy, and S. Yammen, "Performance evaluation of a $10 \mathrm{kWp} \mathrm{PV}$ power system prototype for isolated building in Thailand," Renewable Energy, vol. 32, no. 8, pp. 1288-1300, 2007.

[5] P. Kamkird, N. Ketjoy, W. Rakwichian, and S. Sukchai, "Investigation on temperature coefficients of three types photovoltaic module technologies under Thailand operating condition," Procedia Engineering, vol. 32, pp. 376-383, 2012.

[6] D. Wolpert and P. Ampadu, Managing Temperature Effects in Nanoscale Adaptive Systems, Springer, New York, NY, USA, 2012.

[7] S. Islam, A. Woyte, R. Belmans, P. J. M. Heskes, and P. M. Rooij, "Investigating performance, reliability and safety parameters of photovoltaic module inverter: test results and compliances with the standards," Renewable Energy, vol. 31, no. 8, pp. 1157-1181, 2006.

[8] B. Burger and R. Rüther, "Inverter sizing of grid-connected photovoltaic systems in the light of local solar resource distribution characteristics and temperature," Solar Energy, vol. 80, no. 1, pp. 32-45, 2006.

[9] M. Eltawil and Z. Zhao, "Grid-connected photovoltaic power systems: technical and potential problems-a review," Renewable and Sustainable Energy Reviews, vol. 14, no. 1, pp. 112-129, 2010. 
[10] J. Worden and M. Martinson, "How inverters work: what goes on inside the magic box," Solarpro, no. 2.3, pp. 68-85, 2009.

[11] Y. Nakada, H. Takahashi, K. Ichida, T. Minemoto, and H. Takakura, "Influence of clearness index and air mass on sunlight and outdoor performance of photovoltaic modules," Current Applied Physics, vol. 10, no. 2, supplement, pp. S261-S264, 2010.

[12] T. Minemoto, S. Nagae, and H. Takakura, "Impact of spectral irradiance distribution and temperature on the outdoor performance of amorphous Si photovoltaic modules," Solar Energy Materials and Solar Cells, vol. 91, no. 10, pp. 919-923, 2007.

[13] A. Limmanee and K. Chumpolrat, "Changes in spectral irradiance and their effects on PV module performance," in Proceeding of the 6th Conference on Energy Network of Thailand (ENETT '10), 2010.

[14] R. Rüther, G. Kleiss, and K. Reiche, "Spectral effects on amorphous silicon solar module fill factors," Solar Energy Materials and Solar Cells, vol. 71, no. 3, pp. 375-385, 2002.

[15] K. Nishioka, T. Hatayama, Y. Uraoka, T. Fuyuki, R. Hagihara, and M. Watanabe, "Field-test analysis of PV system output characteristics focusing on module temperature," Solar Energy Materials and Solar Cells, vol. 75, no. 3-4, pp. 665-671, 2003. 

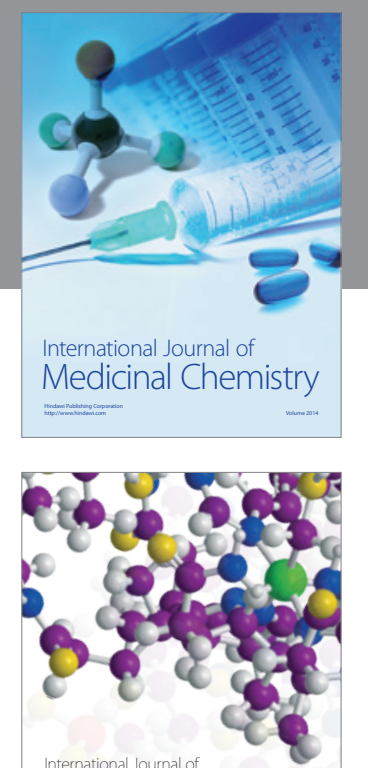

\section{Carbohydrate} Chemistry

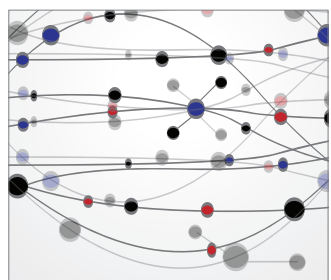

The Scientific World Journal
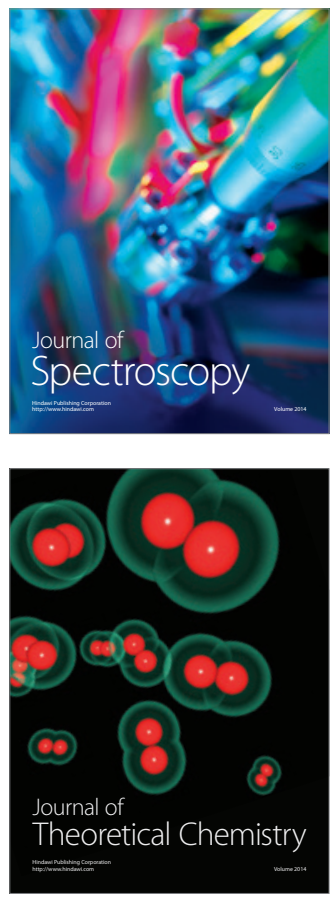
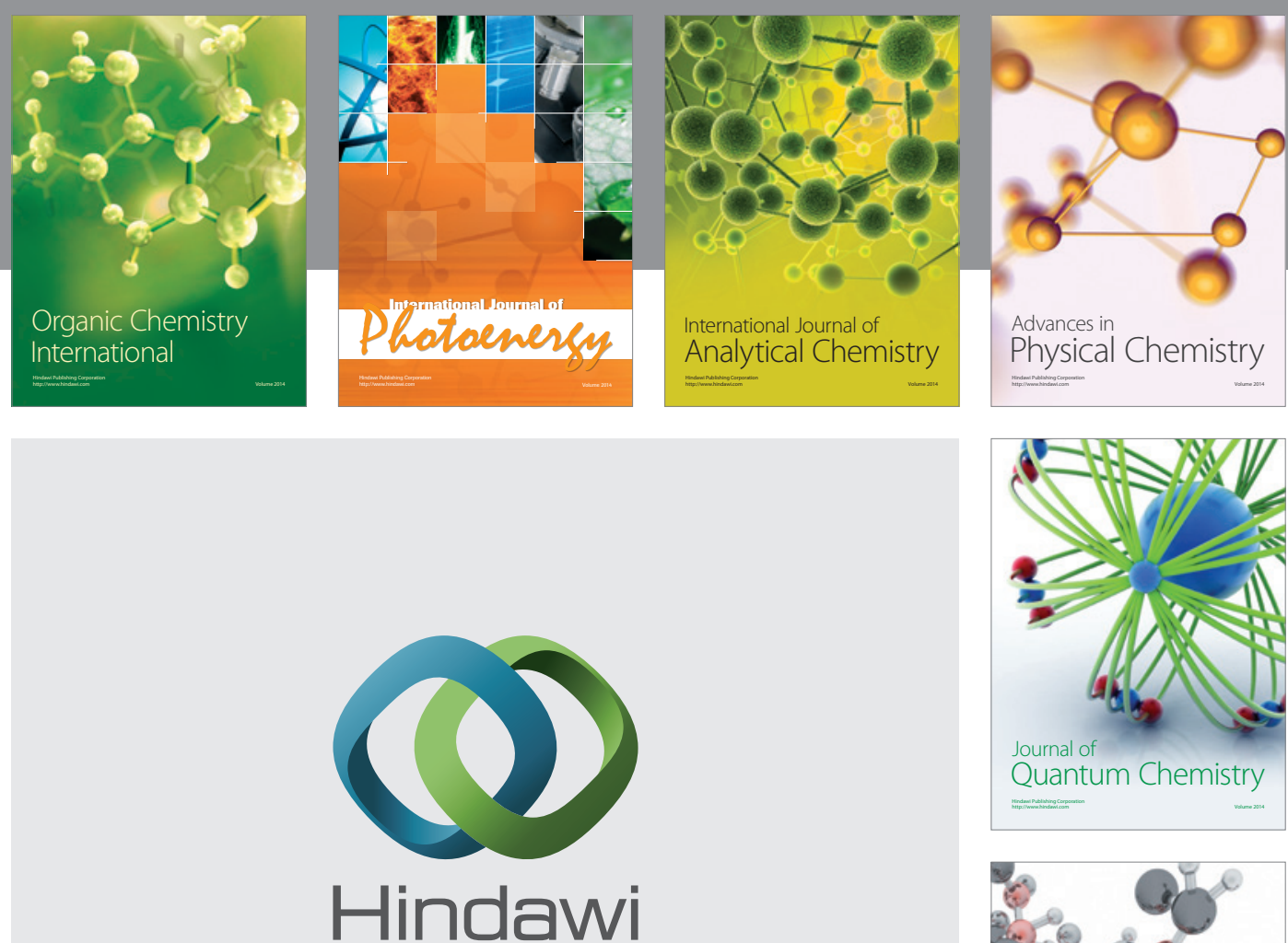

Submit your manuscripts at

http://www.hindawi.com

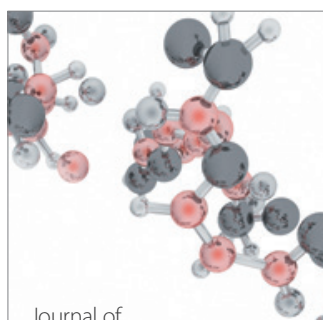

Analytical Methods

in Chemistry

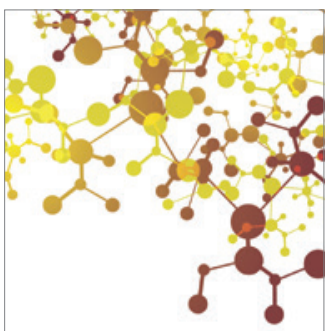

Journal of

Applied Chemistry

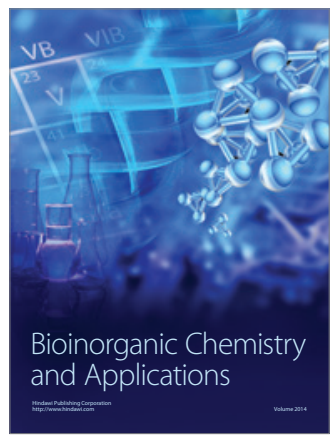

Inorganic Chemistry
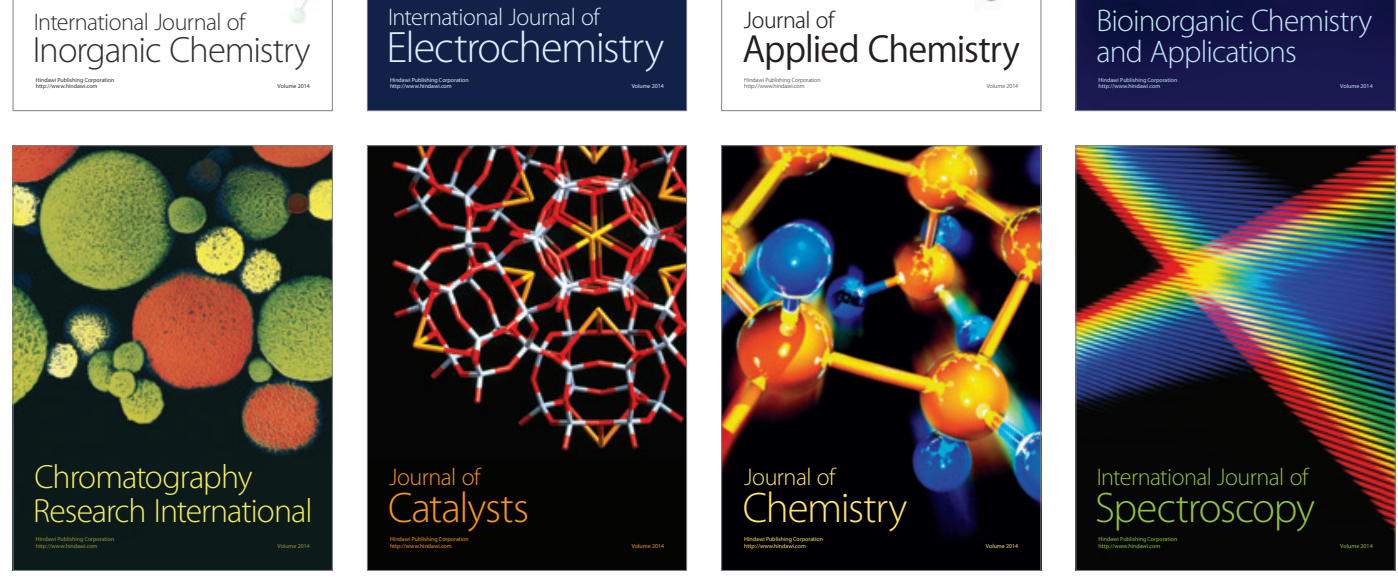